\title{
Analysis of the Country of Origin Effect for the Romanian Consumer of Food Products
}

\author{
Daniel CHICIUDEAN ${ }^{1 *}$, Iulia MUREȘAN ${ }^{1)}$, Marioara ILEA ${ }^{1)}$, Gabriela CHICIUDEAN ${ }^{1)}$ \\ ${ }^{1)}$ Faculty of Horticulture, Department of Economic Sciences. University of Agricultural Sciences and \\ Veterinary Medicine Cluj-Napoca,3-5 Mănăștur St. Romania. \\ ${ }^{*}$ Corresponding authors, e-mails: chiciudean.daniel@yahoo.com
}

Bulletin UASVM Horticulture 71(2) / 2014

Print ISSN 1843-5254, Electronic ISSN 1843-5394

DOI:10.15835/buasvmcn-hort:10596

\begin{abstract}
In the case of food products, the concept of country of origin is frequently present because of the shorter time spend by the consumer during the evaluation of alternatives phase. The aim of this study is to determine the influence of country of origin attribute over the consumer in the case of food products by comparing to attributes like brand, price, package and ingredients. A study was conducted among the people from Cluj-Napoca in 2013, on a sample of 277 people. The instrument used was the questionnaire which had four parts. A major objective of this study was to investigate if the results obtained by Dosen (2006) in his study will be the same among the Romanian consumers. The first hypothesis considers that the brand is more important in the buying decision-making process than the country of origin. The second one refers to price as being more important than the country of origin. Results indicate that price is more important than all the attributes mentioned: country of origin, ingredients, brand, and package. Country of origin is more important than brand and package. Brand is more important than package. In the present study brand is not more important than the country of origin and price is more important than the country of origin. It can be concluded that the country of origin is an important attribute when referring to food products, but price is the most important one. Package is the least important attribute, so not so many efforts must be spent for it.
\end{abstract}

Keywords: food products, brand, price

Introduction: In the case of food products, the concept of country of origin is frequently present because of the shorter time spend by the consumer during the evaluation of alternatives phase. Schnettler et al. (2009) consider that the country of origin effect could be the key element for adding value to products and differentiate from the competition. Philp and Brown (2003) highlight an interesting fact regarding the globalization which instead of reducing the consumer sensitivity towards the products origin, the result was an intensification of the consumers' sensibility toward foreign products. This aspect has huge marketing implications.

Orth and Firbasova (2002) and Dosen et al. (2007) concluded that products from more developed countries are more appreciated than the products from less developed countries. Generally there is a tendency to prefer the products from the consumer country of origin.

Chryssochoidis et al., (2007) connects the country of origin effect with the consumer's attitude towards importated products, observing the negative aspect of this effect especially in the case of those products which must enter on a new market, because the country of origin effect acts like a barrier for the consumer perception.

Dosen (2007) investigated how the young Croatian people use the attribute „country of origin" in evaluating chocolate. Therefore, two hypotheses were established: brand has a stronger influence than the country of origin and price has a stronger influence than the country of origin. The study was conducted on a sample of 278 young 
Croatian people. For the young Croatian brand and price are more important than the country of origin during the buying decision making process.

Aims: The aim of this study is to determine the influence of country of origin attribute over the consumer in the case of food products by comparing to attributes like brand, price, package and ingredients.

Materials and Methods: A study was conducted among the people from Cluj-Napoca in 2013, on a sample of 277 people. The instrument used was the questionnaire which had four parts. The first part comprises the 17 affirmation of the Cetscale based on the American Cetscale by Shimp and Sharma, the second part contains questions related to the consumer attitude towards imported food, the third part towards local food and the fourth part was a socio-demographic section. A major objective of this study was to investigate if the Romanian consumers consider the attribute "country of origin" important during the decision-making process of buying. Beside the attributes established by Dosen (2007) - "country of origin", "brand", "price" in the present study two more elements were included: "ingredients/ recipe" and "package". The questions were built using a 5-point scale from 1-"not important at all" to 5-"very important". Results were interpreted using mean values.

Results: Results indicate that price is more important than all the attributes mentioned (the mean value obtained is 4.21 which indicates that the attribute "price" is more than important to the Romanian consumers). "Ingredients/recipe" is also important to consumers but the mean is only 3.98. The third important attribute is country of origin (mean value 3.46). Country of origin is more important than brand and package. Brand is more important than package. The least important attribute for the Romanian consumers is package with a mean value of 2.94. In the present study the results are very different from the ones obtained by Dosen (2007). So, for the Romanian consumers brand is not more important than the country of origin. Similar to the results obtained by Dosen et al. (2007) the attribute "price" is more important to the Romanian consumers than the country of origin.

Conclusion: It can be concluded that the country of origin is an important attribute when referring to food products, but price is the most important one and ingredients/recipe also. Package is the least important attribute for the Romanian consumers within the analyzed sample. These findings could be useful to agro food marketing because it highlights the attributes considered important to consumers during the decision -making process.

\section{REFERENCES}

1. Chryssochoidis G, Krystallis A, Perreas P (2007). Ethnocentric beliefs and country of origin effect. European journal of marketing. 41(11/12):1518-1544.

2. Dosen OD (2007). Assesments of country of origin and brand cues in evaluating a Croatian western and eastern European food product. Journal of Business Ressearch. 60: 130-136.

3. Orth UR and Firbasova Z (2002). Ethnocentrism and consumer evaluations of Czech made yoghurt, Agricultural Economics, 48(4):175-181

4. Philp Kand Brown L (2003). Does consumer ethnocentrism impact on Australian food buying behaviour?, Journal of new Business ideas and trends, 1(2):21-43

5. Schnettler B, Ruiz D, Sepulveda O, Sepulveda J, Denegri $M$ (2009). Importance of origin in rice purchasing decisions in Talca and Temuco, Chile. Ciencia e investigacion agraria. 36(2):239-248. 